\title{
Study on feeding practices of infants among the mothers in selected villages, at Dhamrai.
}

\author{
(Dr. Mohoshina Karim ${ }^{1}$, Dr. Shayela Farah ${ }^{2}$, Dr.Jannatul Ferdousi ${ }^{3}$ ) \\ ${ }^{1}$ Lecturer, Department of Community Medicine, Dhaka Community Medical College Moghbazar, Dhaka. ${ }^{2}$ Assistant Professor Department \\ of Community Medicine, Dhaka Community Medical College, Moghbazar, Dhaka. ${ }^{3}$ Associate Professor (CC) Department of \\ Community Medicine, Dhaka National Medical College, Jhonson Road, Dhaka.
}

\begin{abstract}
:
Infants are the most vulnerable group among all the groups in our society. Infants constitute about 3\% of the total population of Bangladesh. About 1 new born comes to the earth per 11 seconds in Bangladesh. Breastfeeding of infants is an essential health and medical decision for both the mother and her baby. Breastfeeding results in significant health gain, obesity reduction and cost saving to society. Breastfeeding decisions and practices are influenced by multiple factors including knowledge, attitudes and beliefs, as well as socio-cultural and physiological factors. This was a rural based cross sectional descriptive study carried out among 320 villagers of selected villages, at Dhamrai upazilla health complex, Dhaka provides information about breast feeding practices \& awareness regarding usefulness of it from 7th December to 30th December 2011. Result shows, $48.1 \%$ of the respondents were from the age group of 21-25 years. The mean age of the respondents was $25.34 \mathrm{yrs} \& \mathrm{SD}= \pm 4.281$. About half of the respondents $151(47.2 \%)$ had primary education \& $96(30 \%)$ had secondary education. Most of the respondents 301(94.1\%) were housewife, 14(4.4\%) were service holder and $\mathbf{5}(\mathbf{1 . 6 \%})$ were agriculture worker. The mean monthly family income of the respondents was 7626.56 \pm 3171.248 Taka. Out of 320 respondents about $137(42.8 \%)$ of the responding mothers continued breast feeding to their babies for 9-12 months and 239 $\mathbf{9 1 . 6 \% )}$ weaned their babies at correct times that means within 6 months of life. The present study showed that most mothers $315(98.4 \%)$ were aware about the usefulness of breast feeding, we found $218(68.1 \%)$ had the knowledge of starting weaning food. The present study was done in selected villages of Dhamrai, covering a small group of population which does not represent the whole nation. Therefore, a large scale community based study is needed to know the real situation of the country.

Key words: Knowledge, breast feeding, colostrum, weaning.
\end{abstract}

Introduction:

Under any circumstances breast milk is the ideal food for the infants.

Breast milk provides the main source of nourishment in the $1^{\text {st }}$ year of life. In some societies lactation continues to make and important contribution to the child nutrition for 18 month or longer. In the world's more affluent societies, breast feeding appears to have become a lost art \& the feeding bottle has usurped to the breast. ${ }^{1}$ When the standard of environmental sanitation is poor \& education low, the content of the feeding bottle is likely to be as nutritionally poor as it is bacteriologically dangerous. It is therefore very important to advice the mothers to avoid the feeding bottles.
An average Indian mother, although poor in nutritional status, has a remarkable ability to breast feed her infant for prolonged periods, sometimes extending to nearly 2 years. A cross sectional study indicates that poor Indian women secrete as much as 400 to $600 \mathrm{ml}$ of milk per day during the $1^{\text {st }}$ year. ${ }^{2}$ No other food is required to be given 6 month after birth. At the age of 6 months breast milk, should be supplemented by additional foods rich in protein and other nutrients (animal milk, soft-cooked massed vegetables, etc). These are called supplementary food which should be introduced gradually in small amount. Breast feeding should be initiated within an hour of birth. Instead of waiting several hours as is often 
customary. Although there is little milk at the time, it helps to establish feeding and close mother's child relationship, known as bonding. The first milk which is called colostrum is the most suitable food for the baby during early period, because it contains a high concentration of protein and other nutrients the body needs; it is also rich in anti-infective factors which protect the body against respiratory infections and diarrhoeal diseases supplementary feeds are not necessary .The regular milk comes on the $3^{\text {rd }}$ to $6^{\text {th }}$ days after birth. The baby should be allowed to breast milk whenever it wants. Feeding the baby on demands helps the baby to gain weight. It is very important to advice mother to avoid feeding bottles. ${ }^{3}$

A child who is breast-fed has greater chances of survival than a child artificially feed. Prolonged breast feeding does protect the infant from early malnutrition and some infections. The data suggest IMR in developing countries are 5 to 10 times higher among children who have not been breast feed or who have been breast feed for less than 6 months. Despite the marked advantages of breast feeding, its popularity has decline significantly in many parts of the world. The artificial feeding are the breast milk substitute and are dried whole milk powder, cow's milk or other animal or commercial formulae and are the failure of breast milk or prolonged illness of mother. Artificial feeding is a hazardous procedure in homes because of the danger of the contamination and over dilution of the fat. Human milk contains low protein, more cystine. It is rich in iodine, in dispensable for infants. Breast milk is almost completely digested and utilized for growth. It contains other proteins whose functions are anti-infective. Mother's milk also rich in fats and contains more lactose. Human milk contains vitamins and minerals in sufficient amount. Weaning started gradually around the age of 6 month. It should be supplemented by suitable foods which in protein and other nutrients. These are called supplementary food. These are usually cow's milk, fruits juice, soft cooked rice, dhal and vegetables. The weaning period is most crucial period in child development. For during the weaning process children are particularly exposed to the deleterious synergistic interaction of malnutrition and infection. If not done properly is often followed by diarrhoea, kwashiorkor and marasmus. Knowledge of weaning foods and practices is an important aspect of child health $\&$ development. At the age of 1 year the child should receive solid foods consisting of cereals, pulses, vegetables and fruits. Efforts should be therefore be made to design and promote the use of feeding practice of infants. ${ }^{3}$

\section{Methods and materials:}

This was a cross sectional descriptive study to determine the feeding practice of infants among the mothers in selected village, at Dhamrai. Lactating mother who had baby up to 1 year were included in the study population and those were 1 year and above were excluded. The study was conducted at Dhamrai, Dhaka.

The study was conducted for a period of $7^{\text {th }}$ December to $30^{\text {th }}$ December, 2011. Within this period data was collected for 10 days.

In this study the sample size was 320 due to limitation of time. Simple random sampling technique was adopted to select the sample of population. A structured questionnaire was developed keeping the objectives and variables to be studied in the mind. The questionnaire was two parts consisting of sociodemographic characteristics \& feeding related variables. Face to face interview technique was used to collect data. The data was collected, checked, verified and then enter into the computer. Only the fully completed questionnaire was entered into the computer for final analysis. The analysis was carried out with the help of SPSS (Statistical package of social science, version-17), Windows software program.

\section{Result:}

Out of 320 respondents most of the respondents 154(48.1\%) were in the age group of 21-25 years. This is followed by 107 $(33.4 \%) \& 33(10.3 \%)$ in the ages of 20 years. (Table:1). Regarding educational qualification of the mothers table 2 shows that primary education level of the respondents were $151(47.2 \%)$, followed by secondary education level are $96(30 \%)$ and illiterate mothers were 71(22.2\%) (Table:3). Out of 320 respondents $190(59.4 \%)$ belongs to nuclear family,129(40.3\%) joint family and rest of $1(0.3 \%)$ were extended family (Table-4) and their monthly income 5001$10000 \mathrm{Tk}$ were 149(46.6\%) followed by 132(41.3\%)having monthly income less than or equal $5000 \mathrm{Tk}$ (Table-5). Regarding age of infants, out of 320 respondents $137(42.8 \%)$ belongs to age group 9-12 months, among others 124(38.8\%), $59(18.4 \%)$ of the respondents were 6-9 months and less than 6 month of age group. (Table-6). Among 320 infants, most infants $96(30 \%)$ were more than $8 \mathrm{~kg}$ and 95(29.7) were 6-8kg and 53(16.6\%) were less than $4 \mathrm{~kg}$ (Table-7). Regarding breast feeding $284(88.8 \%)$ of the respondents getting breast feed and 
the rest 36(11.3\%) did not get breast feed from mother (figure 1). Out of 320 respondents $137(42.8 \%)$ breastfed their infants by the duration of 9-12 months and $124(38.8 \%) \& 59(18.4 \%)$ were 6-9 months and less than or equal to 6 months (Table-8). Among them 145(45.3\%) were given breast fed 3-4 times in a day and 116(36.3\%) more than 4 times a day (Table-9). Out of 320 respondents $160(50 \%)$ did not know the reasons for not given exclusive breastfeeding, 90(28.1\%) were ill and $15.6 \%$ due to insufficient breast milk.(Table- 10). 224 respondents (70\%) were given exclusive breast feeding and $96(30 \%)$ were not given(figure:2). Out of 261 respondent's $91.6 \%$ were taking weaning food and $8.4 \%$ were not taking weaning food(figure:3) and 315(98.4\%) were aware about the usefulness of breast feeding and 5(1.6\%) were not. (Figure:4). Among them 269(84.1\%) were aware about the knowledge on complementary food and 51(15.9\%) were not.( Figure: 5)

\section{Discussion:}

The first year of an infant's life is the period of most rapid growth and an important nutrition transition, when infants are given various types of complementary foods along with breast milk. The present study was done with a view to detect the breast feeding practices \& awareness regarding usefulness of it among the mothers of a selected village at Dhamrai from $7^{\text {th }}$ December to $30^{\text {th }}$ December. It was a cross sectional descriptive study \& total 320 sample were studied. Structured pretested questionnaire were used to collect data. SPSS V-17 package were used for data analysis.

It was found that $48.1 \%$ of the respondents were from the age group 21-25yrs. The mean age of the respondents was 25.34 yrs and $\mathrm{SD}= \pm 4.281$. Among others $33.4 \%, 10.3 \%, 8.1 \%$ of the respondents respectively in the age group 26-30 years, $\leq 20$ years, $>30$ years (Table 1). These findings were more or less similar with findings conducted by Ali MA, Fakir M, Rahman $\mathrm{MM}$, et al. in their study done in Dinajpur District. ${ }^{4}$

About half of the respondents $151(47.2 \%)$ had primary education \& 96(30\%) had secondary education. Most of the respondents $301(94.1 \%)$ were housewives, $14(4.4 \%)$ were service holders and 5(1.6\%) were agriculture workers. The mean monthly family income of the respondents were 7626.56 \pm 3171.248 Taka(Table-5). These findings were almost similar with the findings of "Infant Feeding Practice by the Rural Mothers of Dinajpur District" conducted by Haque M J, Rahman MM, Sarker SK,et al. Their studied also shows that most of the respondents $(86.5 \%)$ were house wives and the mean monthly family income was Taka 4652.26 only. This was quite high per capita income of Bangladesh. ${ }^{5}$ This might be due to location of study place and overall educational status of the respondents.

More than 190(59.4\%) of the respondents were nuclear family, $129(40.3 \%)$ and only $1(0.3 \%)$ belongs to joint family and extended family (Table-4). Out of 320 respondents about $137(42.8 \%)$ of the responding mothers continued breast feeding to their babies for 9-12 months and 239 (91.6\%) weaned their babies at correct times that means within 6 months of life. Another study done by Haque M. which revealed that only $47.7 \%$ mothers continued breast feeding for one yrs and $32.5 \%$ weaned their babies. More or less similar findings were observed by several other studies. Some authors in their study showed that mean duration of exclusive breast feeding and that of continuation of breast feeding were 4-9 months and 10.5 months, practiced by the mothers., ${ }^{3,6,7}$

Haque $\mathrm{M} \mathrm{J}$, et al. conducted a study on "Infant Feeding Practice by the Rural Mothers of Dinajpur District". ${ }^{4}$ The results shows that the common weaning food were Suji (43.5\%). Khichuri (36.1\%), boiled eggs (25.6\%) and fruit juice (24.4\%) which was more or less similar to this study where Khichuri/ Hotchpotch was taken 92(49.7\%), Suji 47(21.5\%) and mixed food 57 (30.7\%).

A national campaign for the protection and promotion of breastfeeding (CPPBF) was launched in 1989 to improve the breastfeeding situation in the country. Workshops were conducted in the different Medical College Hospitals in the country, to create awareness about the importance and benefits of breastfeeding, and to suggest the introduction of breastfeeding policies in hospitals. ${ }^{8}$

The present study showed that most mothers 315(98.4\%) were aware about the usefulness of breast feeding. These findings are almost similar with findings conducted by Li M Wen, et al. in "Intention of breast feeding and awareness of health recommendations: findings from first-time mothers in southwest Sydney, Australia" " Breast feeding decisions and practices are influenced by multiple factors including knowledge, attitudes and beliefs as well as socio-cultural and physiological factors. ${ }^{10-14}$ However, results from research into determining these factors to date have been very variable due to a lack of objective, reliable, valid and sensitive measures. ${ }^{10}$ In developed countries like Australia, mothers who are younger (under 25 years old), have less education, or are most socio-economically disadvantage tend to have lower rates of full breast feeding, rates of initiation and duration of breast feeding. ${ }^{15-16}$

A descriptive cross sectional study on mother's knowledge and practice related to weaning at Butajira, S.Ethiopia in 1994 revealed that $68 \%$ children were on weaning diet. ${ }^{17}$ This findings was similar to our results where we found 218 $(68.1 \%)$ had the knowledge of starting weaning food. 
J. Dhaka National Med. Coll. Hos. 2012; 18 (02): 30-36

Table-1. Distribution of mother's age $\quad[n=320]$

\begin{tabular}{|c|c|c|}
\hline Age group & Frequency & Percent \\
\hline$\leq 20$ years & 33 & 10.3 \\
\hline $21-25$ years & 154 & 48.1 \\
\hline $26-30$ years & 107 & 33.4 \\
\hline$>30$ years & 26 & 8.1 \\
\hline Total & 320 & 100.0 \\
\hline
\end{tabular}

Mean $=25.34 ;(\mathrm{SD}= \pm 4.281)$

Table-2. Distribution of mother's educational qualification $[\mathrm{n}=320]$

\begin{tabular}{|l|c|c|}
\hline $\begin{array}{c}\text { Educational } \\
\text { qualification }\end{array}$ & Frequency & Percent \\
\hline Illiterate & 71 & 22.2 \\
\hline Primary level & 151 & 47.2 \\
\hline Secondary level & 96 & 30.0 \\
\hline $\begin{array}{l}\text { Higher Secondary \& } \\
\text { above }\end{array}$ & 2 & .6 \\
\hline Total & 320 & 100.0 \\
\hline
\end{tabular}

Table-3. Distribution of mother's by occupation [n=320]

\begin{tabular}{|c|c|c|}
\hline Occupation & Frequency & Percent \\
\hline House wife & 301 & 94.1 \\
\hline Agriculture & 5 & 1.6 \\
\hline Service holder & 14 & 4.4 \\
\hline Total & 320 & 100.0 \\
\hline
\end{tabular}

Table-4. Distribution of the respondents by type of family [n=320]

\begin{tabular}{|c|c|c|}
\hline Type of family & Frequency & Percent \\
\hline Nuclear & 190 & 59.4 \\
\hline Joint family & 129 & 40.3 \\
\hline Extended family & 1 & 0.3 \\
\hline Total & 320 & 100.0 \\
\hline
\end{tabular}

Table-5. Distribution of the respondents by monthly family income $\quad[\mathrm{n}=320]$

\begin{tabular}{|l|c|c|}
\hline Family income & Frequency & Percent \\
\hline$\leq 5000 \mathrm{Tk}$ & 132 & 41.3 \\
\hline $5001-10000 \mathrm{Tk}$ & 149 & 46.6 \\
\hline$>10000 \mathrm{Tk}$ & 39 & 12.2 \\
\hline Total & 320 & 100.0 \\
\hline
\end{tabular}

Mean $=7626.56 ;(\mathrm{SD}= \pm 3171.248)$

Table-6. Distribution of the respondents by age of infants [n=320]

\begin{tabular}{|c|c|c|}
\hline Age of child & Frequency & Percent \\
\hline$\leq 6$ months & 59 & 18.4 \\
\hline 6-9 months & 124 & 38.8 \\
\hline 9-12 months & 137 & 42.8 \\
\hline Total & 320 & 100.0 \\
\hline
\end{tabular}

Mean $=8.44 ;(\mathrm{SD}= \pm 3.082)$

Table-7. Distribution of the infants by weight $\quad[n=320]$

\begin{tabular}{|c|c|c|}
\hline Weight & Frequency & Percent \\
\hline$\leq 4 \mathrm{Kg}$ & 53 & 16.6 \\
\hline $4-6 \mathrm{Kg}$ & 76 & 23.8 \\
\hline $6-8 \mathrm{Kg}$ & 95 & 29.7 \\
\hline$>8 \mathrm{Kg}$ & 96 & 30.0 \\
\hline Total & 320 & 100.0 \\
\hline
\end{tabular}

Mean $=7.049(\mathrm{SD}= \pm 2.5827)$

Figure-1. Distribution of the infants by getting breastfeeding $[\mathrm{n}=320]$
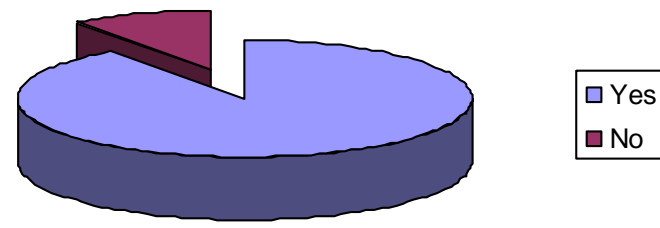
Table-8. Distribution of the respondents by duration of breastfeeding

$[\mathrm{n}=320]$
\begin{tabular}{|c|c|c|}
\hline $\begin{array}{c}\text { Duration of } \\
\text { breastfeed }\end{array}$ & Frequency & Percent \\
\hline$\leq 6$ months & 59 & 18.4 \\
\hline 6-9 months & 124 & 38.8 \\
\hline $9-12$ months & 137 & 42.8 \\
\hline Total & 320 & 100.0 \\
\hline
\end{tabular}

Mean $=8.04 ;(\mathrm{SD}= \pm 3.072)$

Table-9. Distribution of the respondents by frequency of breastfeed in a day

$[\mathrm{n}=320]$

\begin{tabular}{|l|c|c|}
\hline Frequency of breastfeed & Frequency & Percent \\
\hline 1-2 times & 59 & 18.4 \\
\hline 3-4 times & 145 & 45.3 \\
\hline More than 4 times & 116 & 36.3 \\
\hline Total & 320 & 100.0 \\
\hline
\end{tabular}

Figure 2. Distribution of the respondents by exclusive breastfeeding

$[\mathrm{n}=320]$

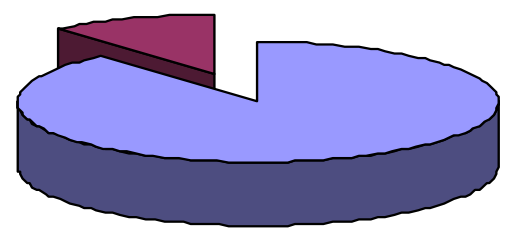

Table-10. Distribution of the respondents by reasons for not given exclusive breastfeeding

[n=320]

\begin{tabular}{|c|c|c|}
\hline $\begin{array}{l}\text { Reasons for not exclusive } \\
\text { breastfeed }\end{array}$ & Frequency & Percent \\
\hline Item Don't know & 160 & 50.0 \\
\hline Illness of mother & 90 & 28.1 \\
\hline $\begin{array}{l}\text { Insufficient of breast } \\
\text { milk }\end{array}$ & 50 & 15.6 \\
\hline Cesarean Section & 20 & 6.3 \\
\hline Total & 320 & 100.0 \\
\hline
\end{tabular}

Figure 3: Distribution of the respondents by taking weaning food $[n=320]$

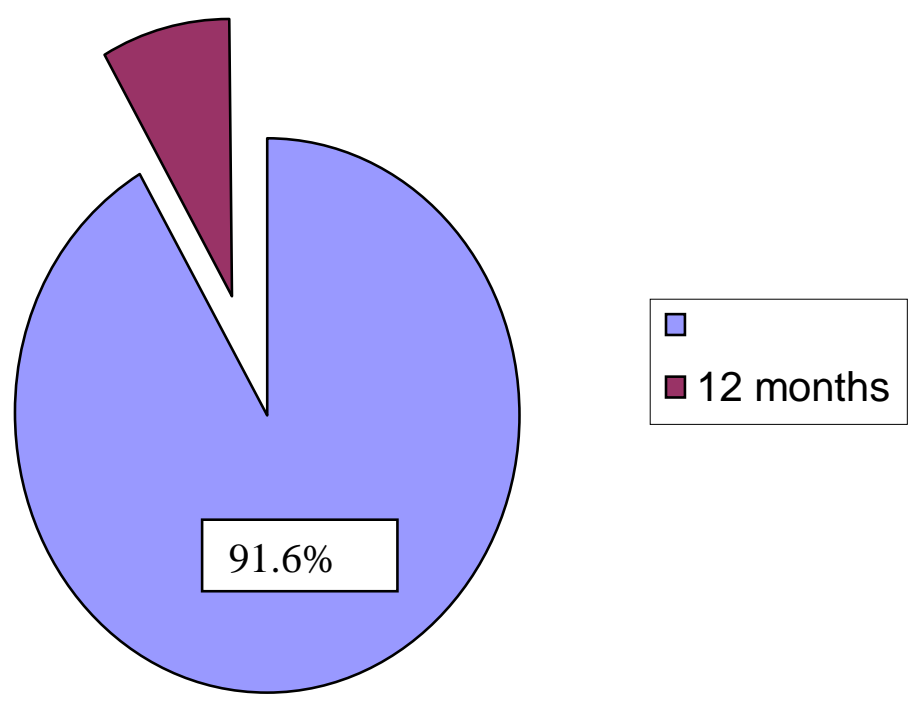

Table-11. Distribution of the respondents by type of weaning food

$[\mathrm{n}=261]$
\begin{tabular}{|l|c|c|}
\hline Type of weaning food & Frequency & Percent \\
\hline Solid food & 59 & 22.6 \\
\hline Semisolid food & 88 & 33.7 \\
\hline Liquid & 65 & 24.9 \\
\hline Others & 49 & 18.7 \\
\hline Total & 261 & 100.0 \\
\hline
\end{tabular}


Table-12. Distribution of the respondents by items of semisolid food

\begin{tabular}{|c|c|c|}
\hline \multicolumn{3}{|l|}{$[\mathrm{n}=185]$} \\
\hline of semisolid food & Frequency & Percent \\
\hline Khichuri (Hotchpotch) & 92 & 49.7 \\
\hline Rice, Vegetable & 25 & 13.5 \\
\hline Fish, Meat & 6 & 3.2 \\
\hline $\begin{array}{l}\text { Multiple answer (Khichuri+ } \\
\text { Rice, Vegetable+ Fish, } \\
\text { Meat) }\end{array}$ & 57 & 30.7 \\
\hline Others & 5 & 2.7 \\
\hline Total & 185 & 100.0 \\
\hline
\end{tabular}

Table-13. Distribution of the respondents by item of soft/liquid

\begin{tabular}{|l|c|c|}
\hline \multicolumn{1}{l|}{ [n=221 } \\
\hline Milem of soft/liquid & Frequency & Percent \\
\hline Burley & 60 & 27.4 \\
\hline Shagu, Suji & 20 & 9.1 \\
\hline Fruit Juice & 47 & 21.5 \\
\hline Milk, Shagu, Suji & 15 & 6.8 \\
\hline Multiple food & 30 & 18.3 \\
\hline Total & 221 & 14.9 \\
\hline
\end{tabular}

Figure 4. Distribution of the respondents by usefulness of breast feeding

$[\mathrm{n}=320]$

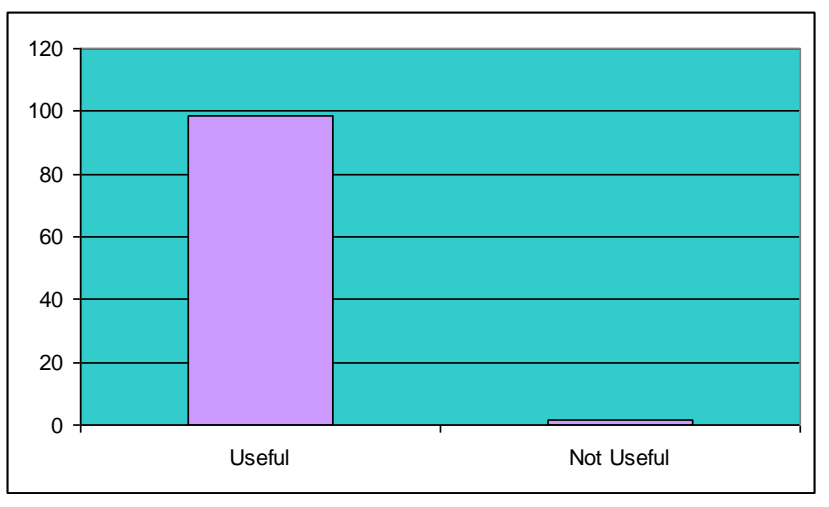

Figure 5: Distribution of the respondents by knowledge on complementary food $[\mathrm{n}=320]$
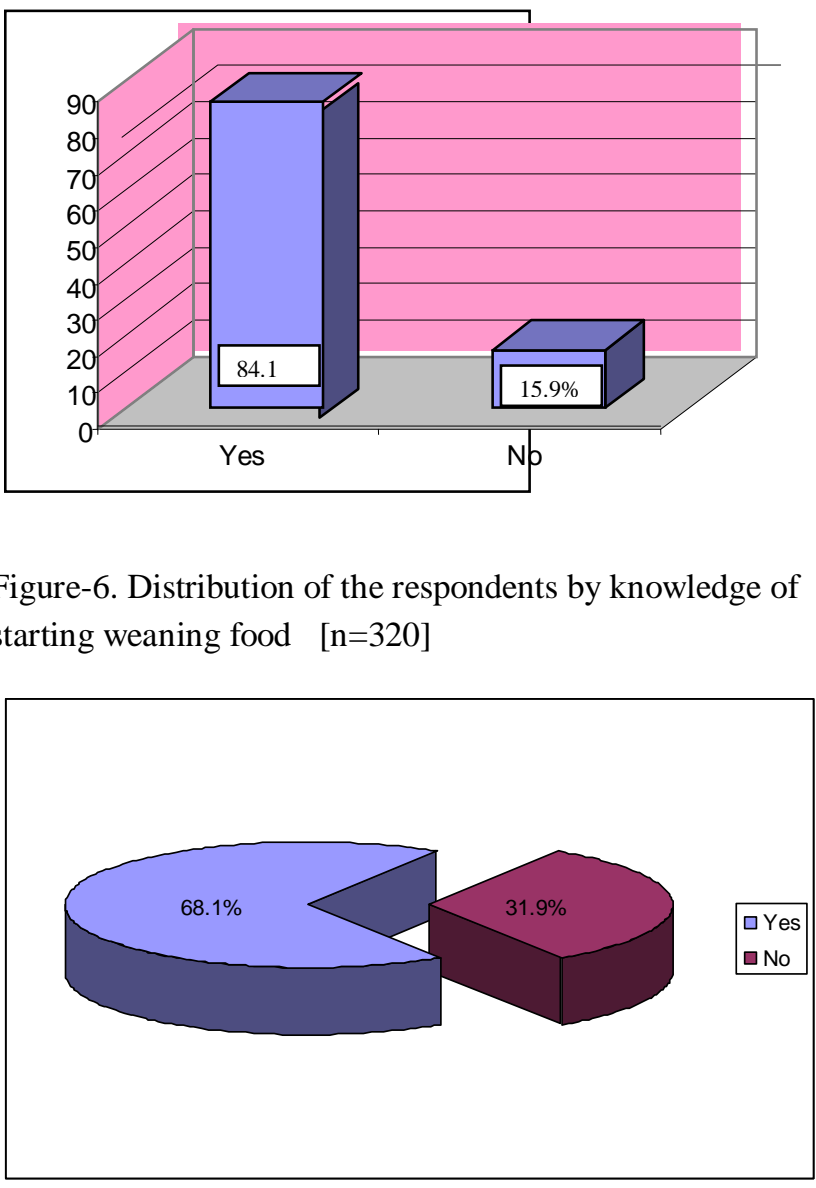

\section{Conclusion:}

This rural based cross sectional descriptive study was carried out among the people of selected villages, at Dhamrai provides information about the prevalence of breast feeding practices and awareness regarding usefulness of it.

Almost $48.1 \%$ of the respondents were from the age group 21$25 y$ rs. Out of 320 respondents about $137(42.8 \%)$ of the responding mothers continued breast feeding to their babies for 9-12 months and 239 (91.6\%) weaned their babies at correct times that means within 6 months of life. About half of the respondents $151(47.2 \%)$ had primary education. Most of the respondents 301(94.1\%) were housewife. The common weaning food were Khichuri/Hotchpotch 92(49.7\%), Suji $47(21.5 \%)$ and mixed food $57(30.7 \%)$ taken by the respondents. The present study showed that most mothers $315(98.4 \%)$ were aware about the usefulness of breast feeding. The most sensitive indicator of health is infant mortality rate as because infants are the most vulnerable group in the society. They are the future generation of the society. If the infants are 
not brought up healthy both physically and mentally they will remain unhealthy through out their life. So practices regarding infant feeding, weaning and rearing should be appropriate and in time to reduce the infant mortality rate and to achieve the key intervention of the Millennium Development Goal 1 and 4.

\section{Reference:}

1. International Planned Parenthood Federation ( 1974). People 1, 45.(Park-26)

2. Someshwar Rao, K. et al (1959). Bull. Wld. Hlth. Org., 20,603.(Park-27)

3. Park K. Park's Textbook of Preventive and Social Medicine. 20th ed. Publishers: Banarsidas Bhanot, Jabalpur, India. Jan. 2005: 457)

4. Haque M J, Rahman MM, Sarker SK, Ali MA, et al.: Infant Feeding Practice by the Rural Mothers of Dinajpur District, Journal/ DjMCJ_V3/ 14_djmcj_v3_il_Jawad_Infant.pd

5. Bangladesh Bureau of statistics, 2002

6. Begum R. Ahmed D. Hossain MS and Bhuiyan MSA. Breastfeeding Practices of Mothers Having Children Under 2 years. Northern Medical journal Sept. 1996; 5(2): 20 - 25.

7. Ullah MA. Sarkar MAM. Haque MJ and Zamman ABMS. Exclusive breast Feeding: Status and Its determinants in a Rural Bangladesh. International Medical Journal March 2004; 11(1): 19-23.

8. Infant feeding practices in rural Bangladesh: policy implications [WP108, 1998] Shameem Ahmed, Ariful Islam, Sadia D Parveen

9. Li M Wen, Louise A Baur, Chris Rissel, et al. Intention of breastfeed and awareness of health recommendations: findings from first-time mothers in southwest Sydney, Australia: International Breastfeeding Journal 2009,4:9

10. Garden F, Hector D, Eyeson-Annan M, Webb K:

Breastfeeding in New South Wales: Population Health survey 2003-2004. Sydney; NSW Centre for Public Health Nutrition, University of Sydney, and Population Health Division, NSW Department of Health;2007

11. Chambers JA, Mclnnes RJ, Hoddinott P, Alder EM: A systematic review of measures assessing mothers' knowledge, attitudes, confidence and satisfaction towards breastfeeding.

12. Papinczak TA, Turner CT: An analysis of personal and social factors influencing initiation and duration of breastfeeding in a large Queensland maternity hospital. Breastfeeding Review 2000,8 (1): 25-33.

13. Kong SKF, Lee DTE: Factors influencing decision to breastfeed. Journal of Advanced Nursing 2004, 46:369-379.

14. Chezem J, Friesen C, Boettcher J: Breastfeeding knowledge, breastfeeding confidence, and infant feeding plans: effects on actual feeding practices.

15. Hector D, Webb K,Lyner S: Describing breastfeeding practices in New South Wales using data from the NSW Child Health Survey, 2001.New South Wales Public health buttetin 2005,16(3-4):47-51.

16. Journal of Obstetric, Gynecology, \& Neonatal Nursing 2003, 32(1):40-47.Feeding:Status and Its determinants in a Rural Bangladesh. International Medical Journal March 2004; 11(1): 19-23.

17. Bekele A, Berhane $\mathrm{Y}$ : Weaning in Butajira, south Ethiopia: a study on mother's knowledge and practice: Ethiopia Med J. 1998 Jan; 36(1):37-4. 